\title{
RAINFALL AND TEMPERATURE EFFECTS ON FLOWERING AND POLLEN PRODUCTIONS IN COCOA
}

\author{
S.S. OMOLAJA, P. AIKPOKPODION, S. OYEDEJI ${ }^{1}$ and D.E. VWIOKO ${ }^{1}$ \\ Plant Breeding Group, Cocoa Research Institute of Nigeria, PMB 5244, Ibadan, Nigeria \\ ${ }^{1}$ Department of Botany, Faculty of Life Sciences, University of Benin, P.M.B. 1154, Benin City, Nigeria
}

(Received 4 April, 2008; accepted 21 July, 2009)

\begin{abstract}
Production of non-functional pollen by plant reduces effectiveness of pollination. A study was carried out at Cocoa Research Institute of Nigeria, Ibadan to determine the influence of rainfall and temperature on flowering intensity of selected clones of Upper Amazon cocoa (Theobroma cacao), as well as its pollen fertility. Eight clones of $T$. cacao used were T17/11, T7/12, T12/5, T86/45, C23, C64, C77 and Pa 24. The number of flowers at varying locations was recorded. The anthers were squashed in acetocarmine, and examined under the microscope to determine pollen fertility of each clone. The result showed that flowering intensity was regulated by rainfall and temperature and varied among the eight clones studied. The number of flowers produced by the various clones ranged from 128 for clone C23, to 415 for clone T86/45 in both January and May. The number of flowers produced on the ventral surface $(V)$ of the clones was significantly higher $(\mathrm{p}<0.05)$ than that from the dorsal region. More pods per cushion would be produced if more of the flowers produced at the dorsal (lower or abaxial) region were pollinated by pollinators in the seed garden. Clone T86/45 had the highest pollen viability (92.11\%), while clone T12/5 recorded the lowest pollen viability ( $81.06 \%$ ).
\end{abstract}

Key Words: Cocoa flowering, Theobroma cacao, Upper Amazon

\section{RÉSUMÉ}

La production de grains de pollen non fonctionnels par les plantes réduit l'efficience de la pollinisation. Une étude avait été réalisée à l'Institut de Recherche sur le Cocoa au Nigéria, Ibadan afin de déterminer l'influence des précipitations et de la température sur l'intensité de la floraison des clones sélectionnés de haute-Amazonie cacao (Theobroma cacao), ainsi que la fertilité de son pollen. Huit clones de T. cacao utilisés avaient été T17/11, T7/12, T12/5, T86/45, C23, C64, de C77, ainsi que Pa 24. Le nombre de fleurs à divers endroits avait été compté. Les anthères avaient été écrasés dans l'acetocarmine et examinés au microscope afin de déterminer la fertilité du pollen pour chaque clone. Le résultat a montré que l'intensité la floraison avait été réglementée par les précipitations et la température dans T. cacao, et elle variait parmi les huit clones étudiés. Le nombre de fleurs produites par les divers clones allant de 128 pour le clone $\mathrm{C} 23$, à 415 pour T86/45 clone aussi bien en janvier qu'en mai. Le nombre de fleurs produites sur la surface ventrale $(V)$ de clones était significativement plus élevé $(\mathrm{p}<0.05)$ que celle de la partie dorsale, par conséquent, plus de gousses par tampon auraient été produites si la plupart de fleurs produites sur la partie dorsale (inférieure ou abaxial) sont pollinisés par les pollinisateurs dans le jardin semencier. Le clone T86/45 avaient la viabilité du pollen plus élevée (92,11\%). Le clone T12/5 a enregistré la viabilité du pollen le plus bas $(81.06 \%)$.

Mots Clés: Floraison du cocoa, Theobroma cacao, Haute-Amazonie 


\section{INTRODUCTION}

Cocoa (Theobroma cacao L.) is a preferentially allogamous Neotropica tree species of the family Malvaceae. Theobroma orginated in several native areas of the tropical rainforest of equatorial America (Bailey et al., 2005), the most important of these being at the foot of the Andes on the upper reaches of the Amazon river (Mossu, 1992). T. cacao is the only species cultivated commercially for producing seeds for preparing chocolate or for extracting cocoa butter. Although, all cultivated cocoas show great variability, it is generally agreed that they can be divided within the species, into three large groups: Criollos, Forastero Amazonians and Trinitarios (Cheesman, 1944; Gordon, 1976). Theobroma cacao, is a tropical understorey tree that is a major economic resource to several tropical countries (Browna et al., 2007; Lanaud et al., 2009;)

The yields of Upper Amazon Cocoa have been militated by several factors since its introduction into Nigeria in 1874. All efforts toward its improvement had been limited partly by inadequate knowledge of the effects of climate on flowering pattern and pollination efficiency. Studies on the influence of season on flowering pattern of cocoa (T. cacao) in various cocoa growing countries showed that flower production is primarily controlled, either directly or indirectly by climatic factors (Alvim, 1984; Mohr and Schopfer, 1994). It has, however, been observed that excessively dry or relatively cold periods may completely inhibit flowering in regions where seasonal variability in rainfall and temperature persist (Alvim 1966; Asomaning et al., 1971). An adult cocoa plant can produce several thousand flowers per year, sometimes more than 50,000 of which only a small proportion (usually less than 5 per cent) are pollinated and an even smaller proportion (0.5 - 2.0 per cent) (Alvim, 1984) produce fruit set. Alvim (1966) reported that environmental factors such as rainfall and temperature had significant effects on flowering and subsequent pod setting.

One of the approaches of genetic improvement of cocoa is based on the creation of hybrids between a number of clearly distinct groups in the species T. cacao. These hybrids are usually distributed as seeds; the production of these latter being assured either by hand pollination or by the creation of biclonal seed gardens if seed production requirements are high (Lachenaud et al., 2009).

Production of non-functional pollen by plants reduces effectiveness of pollination. One of the first steps in assessing effectiveness of pollination in a clonal population is a test of pollen fertility. This gives an indication of the amount of fertile pollen available for pollination by each clone within a seed orchard or plantation. The objectives of the study, therefore, were to determine: (a) the influence of rainfall and temperature on flowering intensity of selected clones of Upper Amazon cocoa; and (b) pollen fertility among selected clones of Upper Amazon cocoa.

\section{MATERIALS AND METHODS}

A field study was carried out at the Cocoa Research Institute of Nigeria Headquarters, IdiAyunre, Ibadan (Lat. $7^{\circ} 26^{\prime} \mathrm{N}$, Long. $3^{\circ} 54^{\prime} \mathrm{E}$, and $122 \mathrm{~m}$ above sea level). The experimental materials consisted of eight clones of T. cacao of Upper Amazon origin. The materials were planted at a spacing of $3.1 \mathrm{~m}$ by $3.1 \mathrm{~m}$, in a polyclonal orchard at N4/4A experimental plot in 1971. The clones were T17/11, T7/12, T12/5, T86/45, C23, C64, C77 and $\mathrm{Pa} 24$.

Description of materials. The codes used for the materials were based on the accepted codes by Cocoa Research Institutes worldwide, as explained below.

T: $\quad$ The code was used by Posnette for seedling materials taken from Trinidad to Ghana in 1944, part of which were introduced into Nigeria;

C: Code used to describe $\mathrm{F}_{2}$ Amazon selection;

Pa: Parinari type of upper Amazon cocoa. This type of cocoa was discovered from river Parinari in Peru;

T12/5: The pod shape is elliptic with an acute apex. It has intermediate basal constriction and the pod size is large, usually about 18 cm long; 
T7/12: The pod shape is obovate with an obtuse apex. The basal constriction is intermediate and possesses a medium pod size, usually $15-17 \mathrm{~cm}$ long;

T17/11: The pod shape is obovate with an indented apex. There is no basal constriction and the pod size is usually large, about $18 \mathrm{~cm}$;

T86/45: The pod shape is elliptic with an obtuse apex and slight basal constriction. The pod size is small to medium, usually 12 14 cm long;

C23: Elliptic pod, acute pod apex with an intermediate basal constriction. The pod size is usually medium to large $(15-17 \mathrm{~cm}$ long);

C64: Elliptic pod, with an obtuse apex and a slight basal constriction. It possesses large pods that is usually greater than 17 cm long;

C77: The pod shape is elliptic with an acute apex. The basal constriction is strong. The pod size is large (above $17 \mathrm{~cm}$ long); and

Pa24: The pod shape is oblong with an acute apex and a slight basal constriction. The pod size is large (above $12 \mathrm{~cm}$ long).

Flowering behaviour. In the flowering experiment, ten trees were randomly selected per clone. The trees were tagged with labels that indicated their clonal type. The main trunk and three branches were selected. Flowers were counted on the main trunk (Tr) between 60 and $120 \mathrm{~cm}$ above ground level, and on the first branch $\left(\mathrm{B}_{1}\right)$, second branch $\left(\mathrm{B}_{2}\right)$ and third branch $\left(\mathrm{B}_{3}\right)$, as well as from the dorsal (D) and ventral (V) regions. The data were taken for two weeks in dry spell of January and two weeks in rainy month of May. The floral structure and patterns of floral initiation were observed. The daily temperature and rainfall figures at Idi-Ayunre, Ibadan were recorded for six months between January and June, for three years: 2006, 2007 and 2008, from which average monthly temperature and rainfall were calculated.

The experimental design used was the randomised complete block design with five replications. The data collected were subjected to analysis of variance (ANOVA) and the means were separated using Least Significant Difference.
Pollen stainability. Anthers were collected from healthy flowers of the selected clones. These flowers were stored in a fixative of aceto-ethanol $1: 3 \mathrm{v} / \mathrm{v}$ in bottles. Then the anthers were mounted on slides to which two drops of acetocarmine were added. The acetocarmine was prepared by adding $0.5 \mathrm{~g}$ of carmine to $55 \mathrm{ml}$ of distilled water and $45 \mathrm{ml}$ of glacial acetic acid were added. The mixture was heated until boiling and the preparation was cooled and filtered. The anthers were squashed in the acetocarmine stain using the base of dissecting needle, after which the tapetal materials were squeezed out using a pair of forceps. The slides were examined under an Olympus microscope. Morphological characters like shape, diameter and stainability of the pollen of each clone were studied.

Well-stained pollen was considered "fertile", while those that were unstainable were considered "sterile". The percentage stainability (fertile) was calculated. The diameters of 10 pollen grains were measured at X400 magnification with ocular micrometer in three random fields of view on three slides mounted for each clone. The means, standard deviations and ranges of pollen measurement taken were determined for each of the clone. Coefficient of variation for the pollen diameter was computed.

\section{RESULTS}

Variation in floral behaviour. Floral initiation varied among the eight clones of Upper Amazon cocoa populations sampled (Table 1). Rainfall and temperature were observed to play significant roles in floral initiation. The number of flowers produced on the ventral surface $(\mathrm{V})$ of the clones was significantly higher $(\mathrm{p}<0.05)$ than from the dorsal region (Table 2). The number of flowers produced by the various clones of Upper Amazon cocoa ranged between 128 for clone C23, and 415 for clone T86/45 in both January and May (Table 2). The increase in mean number of flowers produced by all the clones was higher than $100 \%$ (Table 3 ).

Length of style (pistil). Clonal differences in the length of style were significant $(\mathrm{p}>0.05)$ (Table 4). The style length varied from 2.71 to $7.21 \mathrm{~mm}$ (Table 4). The mean values for individual clones 
TABLE 1. Mean rainfall and temperature records at the Cocoa Research Institute of Nigeria Headquarters, Idi-Ayunre, Ibadan, Nigeria, from January to June for three years: 2006, 2007 and 2008

\begin{tabular}{lcc}
\hline Months & Rainfall $(\mathrm{mm})$ & Temperature $\left({ }^{\circ} \mathrm{C}\right)$ \\
\hline January & 1.0 & 28.4 \\
February & 0.0 & 29.5 \\
March & 74.9 & 29.7 \\
April & 104.4 & 29.7 \\
May & 86.9 & 28.0 \\
June & 244.5 & 28.0 \\
\hline
\end{tabular}

TABLE 2. Number of flowers produced at the dorsal and ventral regions of the eight $T$. cacao clones

\begin{tabular}{lccc}
\hline Clones & Dorsal & Ventral & Total \\
\hline T17/11 & 92.0 & 102.0 & 194.0 \\
T7/12 & 115.0 & 165.0 & 280.8 \\
T12/5 & 108.0 & 148.0 & 256.2 \\
T86/45 & 208.0 & 207.0 & 415.2 \\
C 23 & 35.0 & 93.0 & 128.5 \\
C 64 & 174.0 & 155.0 & 329.7 \\
C 77 & 188.0 & 210.0 & 398.6 \\
Pa 24 & 128.0 & 178.0 & 306.4 \\
& & & \\
Mean & 145.0 & 176.0 & \\
LSD $_{0.0}$ & 23.27 & & \\
\hline
\end{tabular}

TABLE 3. Number of flowers produced by the eight clones in January and May

\begin{tabular}{lccc}
\hline Clones & January & May & \% increase \\
\hline T17/11 & 88.0 & 204.0 & 131.0 \\
T7/12 & 124.0 & 262.0 & 111.0 \\
T12/5 & 103.0 & 253.0 & 145.0 \\
T86/45 & 199.0 & 508.0 & 155.0 \\
C 23 & 45.0 & 130.0 & 188.0 \\
C 64 & 117.0 & 347.0 & 196.0 \\
C 77 & 109.0 & 277.0 & 143.0 \\
Pa 24 & 57.0 & 225.0 & 294.0 \\
& & & \\
Mean & 105.0 & 275.0 & \\
LSD $_{0.05}$ & 58.82 & & \\
\hline
\end{tabular}

ranged from $3.41 \pm 0.38$ to $6.02 \pm 0.85 \mathrm{~mm}$. The style length of clones $\mathrm{T} 17 / 11(3.41 \pm 0.38 \mathrm{~mm})$ and T7/12 (3.71 $+0.74 \mathrm{~mm})$ were shorter, while clone $\mathrm{Pa} 24$ recorded the highest mean style length of $6.02 \pm 0.854 \mathrm{~mm}$.
Pollen stainability. The diameter and shapes of the pollen grain observed in T. cacao clones vary: the shapes were monosulcate, bisulcate, tricolpate, spherical or globose, rectangular and polycolpate (Fig. 1). It was observed that unfertile 
TABLE 4. Style length in the eight clones

\begin{tabular}{lccc}
\hline Clones & \multicolumn{2}{c}{ Style length } & CV. \% \\
\cline { 2 - 3 } & Range $(\mathrm{mm})$ & Mean \pm S.D $(\mathrm{mm})$ & \\
\hline T17/11 & $2.88-3.58$ & $3.41 \pm 0.38$ & 11.26 \\
T7/12 & $2.71-4.49$ & $3.71 \pm 0.74$ & 20.10 \\
T12/5 & $4.64-6.49$ & $4.12 \pm 0.93$ & 22.64 \\
T86/45 & $3.07-5.28$ & $5.92 \pm 0.54$ & 9.14 \\
C 23 & $3.78-5.66$ & $4.40 \pm 0.78$ & 17.71 \\
C 64 & $3.49-5.14$ & $4.19 \pm 0.63$ & 15.18 \\
C 77 & $4.14-5.28$ & $4.72 \pm 0.50$ & 10.60 \\
Pa 24 & $4.92-7.21$ & $6.02 \pm 0.85$ & 14.21 \\
LSD $_{0.05}$ & & 0.80 & \\
\hline
\end{tabular}
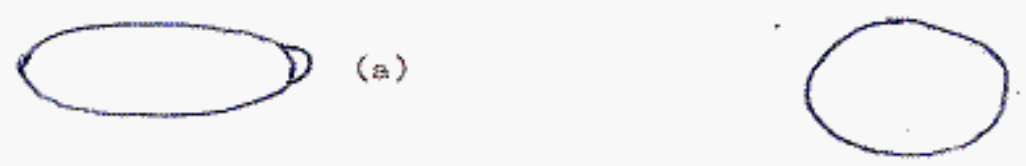

(d)

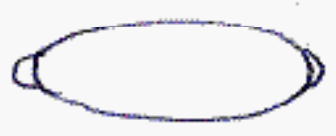

(b)

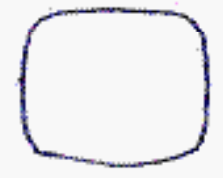

(e)

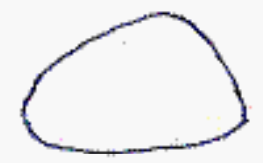

(c)

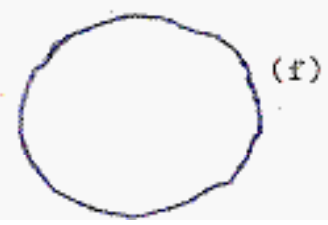

Figure 1. Diagrammatic representation of pollen types in selected clones of Theobroma cacoa. (a) Monosulcate, (b) Bisulcate, (c) Tricolpate, (d) Spherical, (e) rectangular, (f) Polycolpate.

pollen grains did not stain darkly with acetocarmine. The pollen grain diameters of clones T17/11 and T86/45 had the highest C.V. of $40.10 \%$ and $42.03 \%$, respectively (Table 5). Clones C77 and T86/45 had the highest mean pollen diameters of $19.00 \pm 2.21 \mu \mathrm{m}$ and $15.14 \pm 1.36 \mu \mathrm{m}$, respectively. Clone T12/5 had the lowest mean pollen diameter and coefficient of variation (10.77 $\pm 2.81 \mu \mathrm{m}$ and $13.74 \%$, respectively). Generally, the most prevalent shapes of pollen grain were globose $(52.54 \%)$ and monosulcate $(30.33 \%)$ (Table 6). Polycolpate pollen grains were absent in clones T86/45 and C64. Nonetheless, clone T86/45 with pollen viability of $92.11 \%$, was the highest. Clone T12/5 recorded the lowest values $(81.06 \%)$. 
TABLE 5. Pollen diameter in eight clones of Theobroma cacao

\begin{tabular}{lllc}
\hline Clones & \multicolumn{2}{c}{ Pollen diameter } & Coeffient of variation \\
\cline { 2 - 3 } & Range $(\mu \mathrm{m})$ & Mean \pm S.D $(\mu \mathrm{m})$ & \\
\hline T17/11 & $5.25-24.50$ & $12.25 \pm 2.91$ & 40.10 \\
$\mathrm{~T} 7 / 12$ & $7.00-19.25$ & $11.00 \pm 3.28$ & 19.60 \\
$\mathrm{~T} 12 / 5$ & $7.00-21.00$ & $10.77 \pm 2.81$ & 13.74 \\
T86/45 & $8.05-35.00$ & $15.14 \pm 2.36$ & 42.03 \\
C 23 & $10.50-24.50$ & $14.96 \pm 2.46$ & 29.84 \\
C 64 & $7.00-17.50$ & $12.73 \pm 2.75$ & 21.61 \\
C 77 & $14.00-25.20$ & $19.00 \pm 2.21$ & 22.17 \\
Pa 24 & $10.50-21.00$ & $14.06 \pm 3.67$ & 26.11 \\
LSD $_{0.05}$ & & \\
\hline
\end{tabular}

Mean with the same letter are not significantly different at $p<0.05$ according to Least Significant Difference

TABLE 6. Distribution of pollen types and pollen viability in eight clones of Theobroma cacao

\begin{tabular}{|c|c|c|c|c|c|c|c|}
\hline \multirow[t]{2}{*}{ Clones } & \multicolumn{6}{|c|}{ Pollen types viability (\%) } & \multirow[b]{2}{*}{ Mean } \\
\hline & $a$ & b & c & $d$ & e & $f$ & \\
\hline T17/11 & 25.21 & 13.17 & 10.36 & 44.26 & 2.52 & 4.48 & 87.11 \\
\hline $\mathrm{T} 7 / 12$ & 22.14 & 9.16 & 4.58 & 59.29 & 2.80 & 2.03 & 86.01 \\
\hline T12/5 & 28.30 & 13.43 & 8.15 & 45.08 & 1.44 & 3.60 & 81.06 \\
\hline T86/45 & 40.79 & 4.93 & 3.29 & 49.01 & 1.97 & 0.00 & 92.11 \\
\hline C23 & 54.33 & 7.27 & 3.80 & 31.49 & 0.69 & 2.42 & 86.51 \\
\hline C64 & 23.08 & 3.55 & 1.38 & 71.20 & 0.79 & 0.00 & 90.34 \\
\hline $\mathrm{C} 77$ & 27.95 & 7.68 & 2.56 & 59.45 & 0.98 & 1.38 & 90.55 \\
\hline $\mathrm{Pa} 24$ & 20.80 & 10.67 & 5.07 & 60.53 & 2.40 & 0.53 & 86.40 \\
\hline $\begin{array}{l}\text { Mean } \\
\text { LSD }_{0.05}\end{array}$ & 30.33 & 8.71 & 4.90 & $\begin{array}{r}52.54 \\
2.91\end{array}$ & 1.70 & 1.81 & \\
\hline
\end{tabular}

(A) monosulcate; (B) bisulcate; (C) tricolpate; (D) globose; (E) rectanglar and (F) polycolpate. Means with the same small letters are not significantly different at $p<0.05$ according to Least Significant Difference

\section{DISCUSSION}

The highest number of flowers produced among the clones of Theobroma cacao was in May. This observation agrees with earlier reports that flowering intensity is greatest between April and June (Gordon, 1976). The increase in rainfall in May promoted flowering intensity than that observed in January, though both months were warm. Alvim (1966) also observed that flowering intensity is strongly affected by rainfall and temperature. Warm climate and increased rainfall promote flushing and flower initiation in $T$. cacao. Though, flowering intensity was regulated by environmental factors, such as rainfall and temperature in cacao, it varied among the eight clones studied. Mohr and Schopfer (1994) observed that flower initiation, shape and morphogenesis though dependent on the environment is regulated endogenously and varies among cultivars. 
More flowers were found on the ventral (upper or adaxial) region of cocoa trees in this study. This agrees with an earlier observation by Esan (1993) that cacao exhibits a gravimorphic phenomenon for pod production. This suggests that more pods per cushion would be produced if more of the flowers produced at the dorsal (lower or abaxial) region were pollinated in the seed garden. The knowledge of floral structure and pollen viability that affect pod setting is useful in improving the yield and quality of cocoa in Nigeria and the world.

Pollen stainability was highest for clones T86/ 45, C64 and C77, implying that their pollen grains are fertile. Clone T12/5 showed the lowest pollen fertility $(81.06 \%)$. Yield from cocoa trees that are self-incompatible may be depressed by the absence of cross-compatible individuals of good pollen parents (Falque, et al., 1993). The genetic origin of the pollen affects the number of seeds per pod with manual pollination; and in clones highly susceptible to incomplete filling, the introduction of compatible pollen does not suppress the phenomenon (Lachenaud, 1993).

Although not all the factors limiting production in the cacao tree are well known, level of pollination plays a definite role in fruit setting frequency (Falque et al., 1993). Williams and Rouse (1989), however, explained how variation in pollen sizes influence the mode of pollination in plants. The variation observed in various pollen types in this study reveals inter-varietal differences, which could be taken into consideration when grouping variety according to pollen types in the genus Theobroma.

From the study of pollen types among the clones, if hybridisation is considered as the reason for the diversity of pollen types (Carreira and Mederios, 1976), the taxon with the highest combination of types would have the highest hybridisation index and vice-versa. The higher the hybridisation the more advanced such a taxon could be considered to be. The clone with the highest combination of types were T17/11 and $\mathrm{T} 12 / 5$. The mean number of pollen grains produced in the stamens varies with time and is negatively correlated to the percentage of unpollinated flowers (Falque et al., 1993).

\section{CONCLUSION}

High rainfall and favourable temperature promote flowering intensity in cacao in Nigeria. There are differences in pollen viability among clones of Upper Amazon cacao, suggesting that clones with low pollen fertility would not be good candidates for hybrid seed production in cacao.

\section{REFERENCES}

Alvim, P. and de, T. 1966. Factors affecting the flowering of cocoa tree. Cocoa Growers Bulletin 7:15 - 19

Alvim, P. and de, T. 1984. Factors affecting the flowering of cocoa tree. Cocoa Growers Bulletin 35: 23 - 31

Asomaning, E.J. A., Kwakwa, R.S. and Hutcheon, W.V. 1971. Physiological studies on Amazon shade and fertilizer trial at the Cocoa Research Institute. Ghana Journal of Agricultural Science 4: 47-64

Bailey, A. B., Strema, M. D., Baea, H., Antunez de Mayolob, G. and Guiltinan, M. J. 2005. Gene expression in leaves of Theobroma cacao in response tomechanical wounding, ethylene, and/or methyl jasmonate. Plant Science 168: 1247-1258

Browna, J.S., Phillips-Morab, W., Powera, E.J., Krola, C. Cervantes-Martineza, C., Motamayorc, J.C. and Schnella, R.J. 2007. Mapping QTLs for Resistance to Frosty Pod and Black Pod Diseases and Horticultural Traits in Theobroma cacao L. Crop Science 47:1851-1858

Carreira, L. and Mederios, M. 1976. Pollen morphology of woody plants of the camping. Acta Amazonica 6 (3): 247 - 269.

Cheesman, E.E. 1944. Notes on the nomenclature, classification and possible relationships of cacao populations. Tropical Agriculture (Trinidad), 21: 144 - 159.

Esan, E.B. 1993. The effect of gravimorphism on the efficiency of seed pod production in cacao seed orchards. In: Proceedings of the $11^{\text {th }}$ International Cocoa Research Conference, Book of Summaries. Yamoussoukro, Cote d'Ivoire. pp. 637 - 644. 
Falque, M., Vincent, A. and Beaucamp, J. 1993. Relation between amount of pollen deposited on the styles and pod set in Theobroma cacao L. In: Proceedings of the $11^{\text {th }}$ International Cocoa Research Conference, Book of Summaries. Yamoussoukro, Cote d'Ivoire. 18-24 July 1993.

Gordon, J. 1976. Cocoa: Its nature, habitat and cultivation. In: Cocoa Production, Economic and Botanical Perspectives. Springer Publishers Simmons, J. (Ed.). NewYork. Pp 3 $-29$

Lachenaud, P. 1993. Incomplete filling of pods in Cote d'lvoire, description and study of causes. In: Proceedings of the $11^{\text {th }}$ International Cocoa Research Conference, Book of Summaries. Yamoussoukro, Cote d'Ivoire. 18-24 July 1993. pp. 1-15.
Lanaud, C., Fouet, O., Clément, D., Boccara, M., Risterucci, A.M., Surujdeo-Maharaj, S.Legavre, T. and Argout, X. 2009. A metaQTL analysis of disease resistance traits of Theobroma cacao L. Journal Molecular Breeding. 1572-9788 (Online)

Mohr, H. and Schopfer, P. 1994. Plant Physiology. Springer Publishers, New York. pp. 423 - 436.

Mossu, G. 1992. Cocoa. The Tropical Agriculturist, Macmillan Press Limited, London, UK. 103p.

Williams, E.G. and Rouse, J. L. 1989. Relationship of pollen size, pistil length and pollen tube growth rates in Rhododendron and their influence on hybridization. Plant Cell Incompatibility Newsletter 21: 48 - 53. 